\title{
Design of alkali-activated materials for a modular green wall and green roof system
}

\author{
Maria Manso ${ }^{12 *}$, and João Castro-Gomes ${ }^{12}$ \\ ${ }^{1}$ C-MADE, Centre of Materials and Building Technologies \\ 2 Department of Civil Engineering and Architecture, University of Beira Interior, Covilhã, Portugal
}

\begin{abstract}
This study presents the work developed with alkali activated mixtures to be used as component of a new modular green wall and green roof system (GEOGREEN). The aim is to find the most appropriate composition of alkali-activated mixture to maximize water absorption and porosity and also find a good mechanical strength with reduced density. Alkali-activated mixtures were produced using two precursors, mine waste mud from Panasqueira mine (W) and ground waste glass $(\mathrm{G})$ and two alkaline activators, sodium silicate (SS) and sodium hydroxide (SH). A ventilated oven was used to speed up the curing process. Variables as percentage substitution of $\mathrm{W}$ per $\mathrm{G}$, molar concentration of $\mathrm{SH}$, cure length and temperature, were tested to identify the reference mixture. After these tests different percentages of aggregates as sand (S), expanded cork granules (C) and expanded clay (A) were added to reference mixture (REF). Results indicate that S25 obtained the maximum compressive strength of $35 \mathrm{MPa}$ after 7 curing days. However, about $30 \%$ compressive strength loss is observed after immersion of this mixture in water for 24h. Capillary absorption coefficient can reach to $4,77 \mathrm{~kg} / \mathrm{m}^{2} \cdot \mathrm{h}^{0,5}$ with C25 and to $4,11 \mathrm{~kg} / \mathrm{m}^{2} \cdot \mathrm{h}^{0,5}$ with S25. Also C50 enables a $20 \%$ density reduction compared to REF.
\end{abstract}

\section{Introduction}

\subsection{Background}

The construction sector is one of the main waste producer in European Union (EU) representing 35\% of total produced waste. Mine and quarrying comes just after representing around $28 \%$ of total waste production [1]. Therefore it is important to find alternative applications for construction and mine waste, promoting their recicling and reuse.

Panasqueira mine in Portugal generates several hundred tons of coarse aggregate and waste mud every year [2]. Recent research indicates that mine waste mud from Panasqueira mine is rich in silica and alumina and show good reactivity with alkaline activators like sodium silicate and sodium hydroxide allowing to produce alkaliactivated binders [3].

Studies indicate that alkali-activation can be improved by mixing Panasqueira mine waste mud with other sources of amorphous silica [4, 5, 6].

Besides, lightweight aggregates as expanded clay, expanded polystyrene (EPS) or granulated cork are also being tested in several types of cementitious concrete mixtures $[7,8]$.

\subsection{Modular system design}

Environmental conditions of urban areas are becoming deteriorated, due to crescent pollution, densification and lack of green areas. In this context, new solutions of green walls and green roofs are being developed to create vegetated surfaces in buildings [9] without any land occupation [10]. In fact they can be used as a potential strategy of urban rehabilitation [11, 12], having several environmental, social and economic benefits [13]. Recent studies focus on green walls and green roofs ability to improve the urban environment by reducing the heat island effect [14], decrease flood risk and air pollution $[15,16]$, encouraging the fruition of urban areas [17], increase biodiversity [18, 19, 20], and improve quality of life [17]. In a building scale green walls and green roofs can also reduce energy demand for heating and cooling $[21,22,23]$ and improve buildings thermal [24] and acoustic envelope [25, 26, 27].

A new modular system (GEOGREEN) for vegetated surfaces (Fig. 1-3) was designed with the aim of creating more sustainable green roofs and green walls [28, 10, 29]. Based on the reuse of industrial waste, alkali-activated base plate is part of this modular system with the purpose of absorbing water and slowly release it to the plants, minimizing its irrigation needs.

\footnotetext{
* Corresponding author: mcfmm@ubi.pt
} 


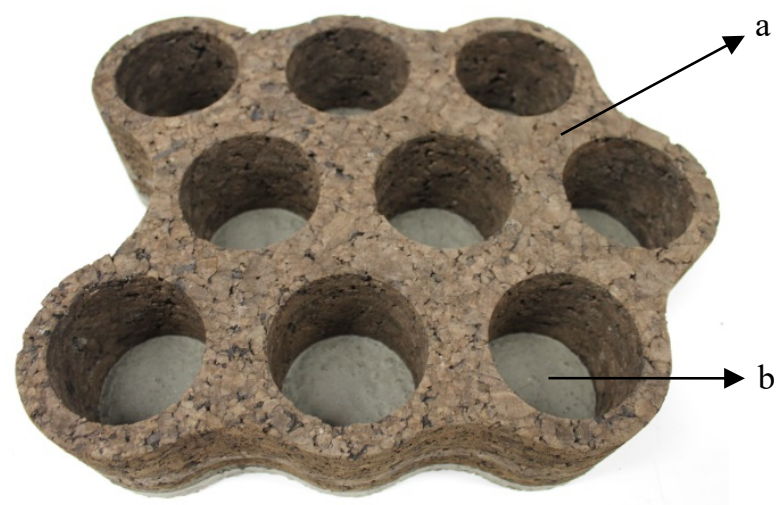

Fig. 1. GEOGREEN module: with lower layer in alkaliactivated binder (a) and upper layer in expanded cork with circular openings (b)

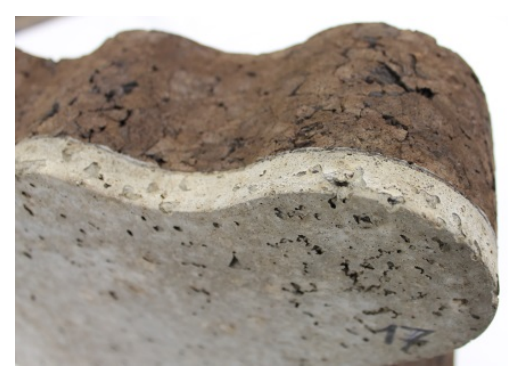

Fig. 2. Alkali-activated binder base applied on the back of GEOGREEN module.

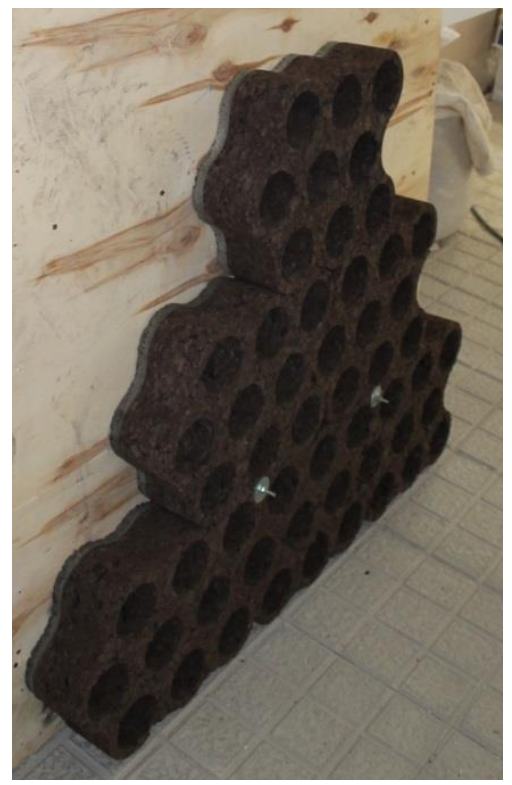

Fig. 3. GEOGREEN modules in vertical position.

\subsection{Goals}

This study aims to identify the composition of alkaliactivated mixtures which have the best characteristics to be used as a component of GEOGREEN. The goal is to develop an alkali activated binder that has good mechanical strength and water absorption, porosity, and lower density than conventional alkali-activated binders.

\section{Materials and Methods}

Several materials make part of the alkali-activated mixtures. As precursors were used waste mud (W) from Panasqueira tungsten mines and milled waste glass $(\mathrm{G})$.

As activators were used sodium silicate (SS) and sodium hydroxide ( $\mathrm{SH})$.

Aggregates like, sand (S), expanded cork granules (C) and expanded clay (A) were also added to the mixture.

Waste mud was obtained from Panasqueira tungsten mine at Portugal. It comes in the form of a powder. Glass bottles were obtained at the local municipality. Glass bottles are cleaned and labels removed. Glass is broken in small particles, dried and sieved with a $125 \mu \mathrm{m}$ sieve. Sand is sieved to obtain the desired particles size.

\subsection{Materials characterization}

Mine waste mud from Panasqueira mines is rich in alumina-silicates and has very good reactivity with alkaline activators like sodium silicate and sodium hydroxide. From the chemical analysis it is evident that mine waste mud is rich in silicon dioxide (52\%) and aluminium oxide $(11 \%)$. The amorphous part of the silica and alumina present in the mud are fundamental for the alkaline activation.

Waste glass has mainly amorphous silica (74\%) in its composition and smaller amounts of oxides of calcium and sodium. Waste glass is milled and sieved under $125 \mu \mathrm{m}$ to be incorporated into the mixture. It is used in the mixture to increase the precursor's percentage of amorphous materials.

Table 1. Oxide chemical composition of mine waste mud and waste glass.

\begin{tabular}{|c|c|c|}
\cline { 2 - 3 } \multicolumn{1}{c|}{} & \multicolumn{2}{c|}{ Constituents (\%) } \\
\hline Oxide & Mine waste mud & Waste glass \\
\hline $\mathrm{SiO}_{2}$ & 51,72 & 73,93 \\
\hline $\mathrm{Al}_{2} \mathrm{O}_{3}$ & 10,53 & - \\
\hline $\mathrm{Fe}_{2} \mathrm{O}_{3}$ & 12,93 & 0,40 \\
\hline $\mathrm{SO}_{3}$ & 10,40 & - \\
\hline $\mathrm{K}_{2} \mathrm{O}$ & 2,68 & 0,69 \\
\hline $\mathrm{CaO}$ & 0,87 & 12,83 \\
\hline
\end{tabular}

As activators were used sodium silicate (SS) D40 and sodium hydroxide with 10-12M molar concentration. In these mixtures was established a ratio of sodium silicate to sodium hydroxide of 4 and a ratio of precursor to sodium silicate of 4,5.

Different types of aggregates like $1-2 \mathrm{~mm}$ river sand (S), 4-8mm expanded cork granules (C) and 1-2mm expanded clay $(\mathrm{A})$ were used in the mixtures. 


\subsection{Synthesis of Samples}

Precursors were mixed together in a dry state until obtaining a uniform mixture. Activators like sodium silicate and sodium hydroxide solution were mixed together in a mixer for 10 minutes at low speed. After mixing the precursor mixture is slowly added to the alkaliactivator solution. After obtaining a homogeneous mixture, water was slowly introduced. Finally, aggregates were added to the mixture.

Alternatively, aggregates surface can be sprinkled first before being inserted into the mixture. The resulting paste was mixed at a lower rate until uniformity was obtained and then placed into the mould. The paste was manually compressed to ensure full mould filling. The mould was covered with plastic to avoid a rapid moisture loss in the beginning of the curing process. Samples were demoulded and left uncovered after 48 hours.

\subsection{Compressive Strength}

Cubic specimens with 40x40x40mm size were prepared for compressive strength testing. Compressive strength was tested using an ELE $3000 \mathrm{kN}$ compression equipment in accordance with EN 196-1 [30], with some adaptations. The recorded compressive strength value was the average of values obtained from six specimens.

\subsection{Water immersion}

Specimens with $40 \times 40 \times 40 \mathrm{~mm}$ size of each mixture were also produced to identify if mixtures mechanical strength is affected by water. Six specimens of each mixture were tested after a curing period of 7 days. All samples were allowed to cool after curing and then inserted in a tin with approximately 1 litre of water at room temperature for $24 \mathrm{~h}$. This was considered the time necessary to get specimens saturated. After each immersion period, specimens were removed from water, dried until constant mass acquired and submitted to a compressive strength test in accordance with EN196-1 [30], with some adaptations.

\subsection{Capillarity Water Absorption}

Capillarity is defined as the penetration of a liquid into the material by effect of surface tension generated at the water-air-wall pores interface. Water penetration depends normally of the quantity, size, shape and pores connectivity in the material structure. Test samples were prepared according to the Portuguese Specification E3931993 - Concretes, with some adaptations. Five samples with $4 \times 4 \times 14 \mathrm{~cm}$ of each mixture were prepared to perform this test. Samples were dried at a constant temperature until constant mass is acquired, then allowed to cool at room temperature. Test samples were inserted into a tray with 5 to $10 \mathrm{~mm}$ of water above the underside of the samples. Measurements were made at the end of $3 \mathrm{~h}, 6 \mathrm{~h}$, $24 \mathrm{~h}$ and $72 \mathrm{~h}$ from the moment samples were placed in contact with water.

\section{Results and discussion}

Prior to adding aggregates to the mixture, some characterization tests were performed to identify the reference mixture. In this context different molar concentrations, waste glass percentages and curing times were tested.

\subsection{Influence of glass substitution on mixtures compressive strength}

This analysis is based on a replacement of a percentage of $20 \%$ to $30 \%$ of mine waste mud (W) by milled waste glass (G). Each result reflects the average value from six specimens per each $\mathrm{G}$ replacement value and age. These mixtures were tested after 7,14 and 28 days curing at a constant curing temperature of $60^{\circ} \mathrm{C}$.

In Fig. 4 it can be observed that for 7 curing days the compressive strength increases with the addition of $G$ content in the mixture. However, the increase of strength is not so marked in longer curing periods. W70G30 specimen shows even a loss of strength after a 14 curing days. In fact mixture W80G20, with a lower G content, was the mixture that presented a greater increase of strength over time. Therefore this mixture was used forward as reference mixture.

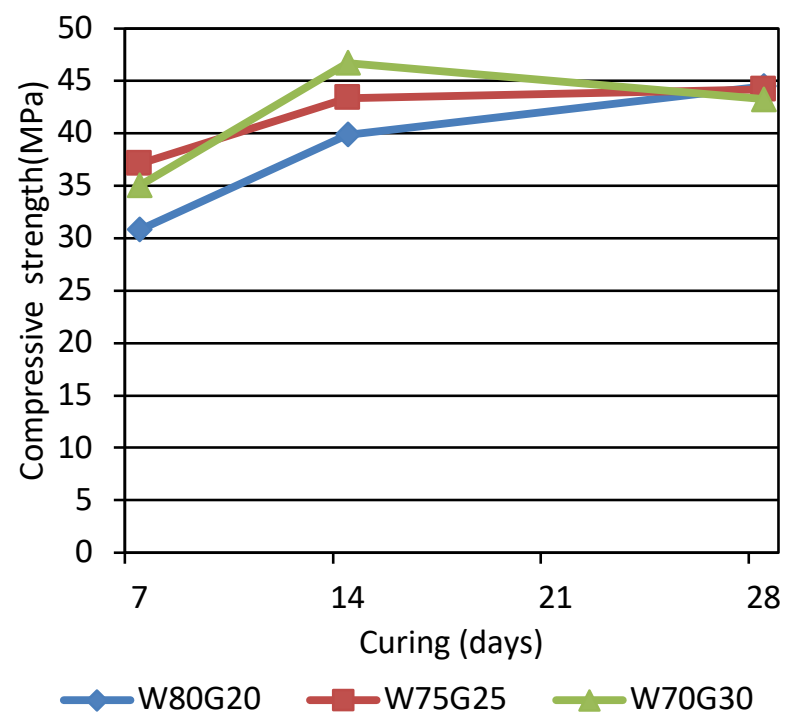

Fig 4. Compressive strength of alkali-activated mixtures with $20 \%$ to $30 \%$ of $\mathrm{W}$ replacement by $\mathrm{G}$.

\subsection{Influence of sodium hydroxide molar concentration in compressive strength}

Considering that mixture W80G20 demonstrated a better behaviour it was used as reference for the following studies. In this case different molar concentrations of sodium hydroxide were tested to identify its compressive strength with different curing periods (Fig.5). Results indicate that mixtures with $12 \mathrm{M}$ present slightly higher 
compressive strength in shorter curing periods of 7 days. However the strength results are very similar for $10 \mathrm{M}$ and $12 \mathrm{M}$ concentrations.

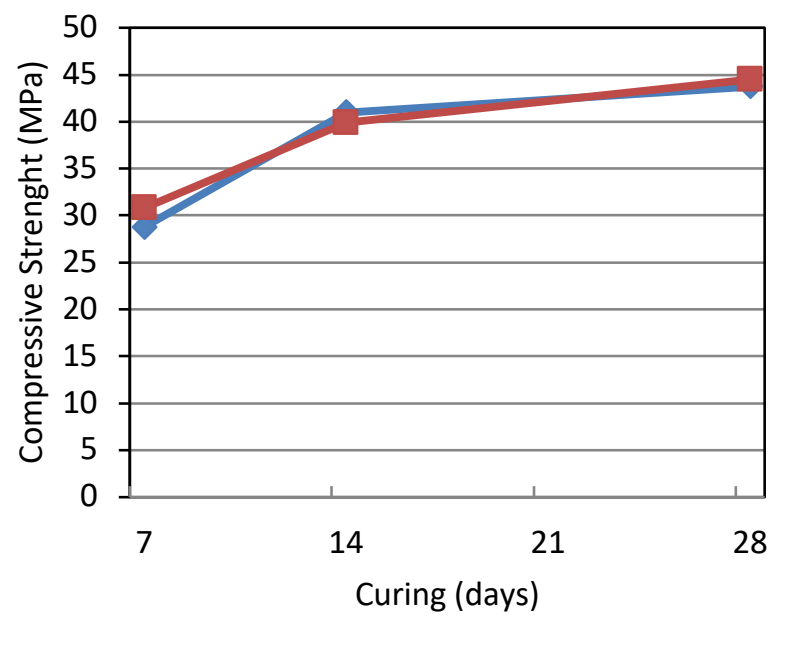

$\sim$ W80G2010M W80G2012 M

Fig 5. Compressive strength of alkali-activated mixtures with different SH molar concentrations.

\subsection{Influence of curing temperature in compressive strength}

The influence of curing temperature was also identified (Fig. 6). Curing at $60^{\circ} \mathrm{C}$ presents a continue increase of compressive strength along the time. The same doesn't happen if the cure is increased from $60^{\circ} \mathrm{C}$ to $80^{\circ} \mathrm{C}$. Specimens cured at $80^{\circ} \mathrm{C}$ show the highest compressive strength, $44 \mathrm{MPa}$, when cured for 7 days. However there is a $26 \%$ loss of strength when curing is increased from 7 to 14 curing days.

If the cure is prolonged from 14 to 28 days the tendency of both mixtures is to increase their strength.

Ideally curing time and temperature should be minimized when possible to reduce the embodied energy of alkali-activated mixture and consequently the $\mathrm{CO}_{2}$ emissions regarding its production. The results indicate that a good compressive strength is reached at 7 days with a curing temperature of $60^{\circ} \mathrm{C}$.

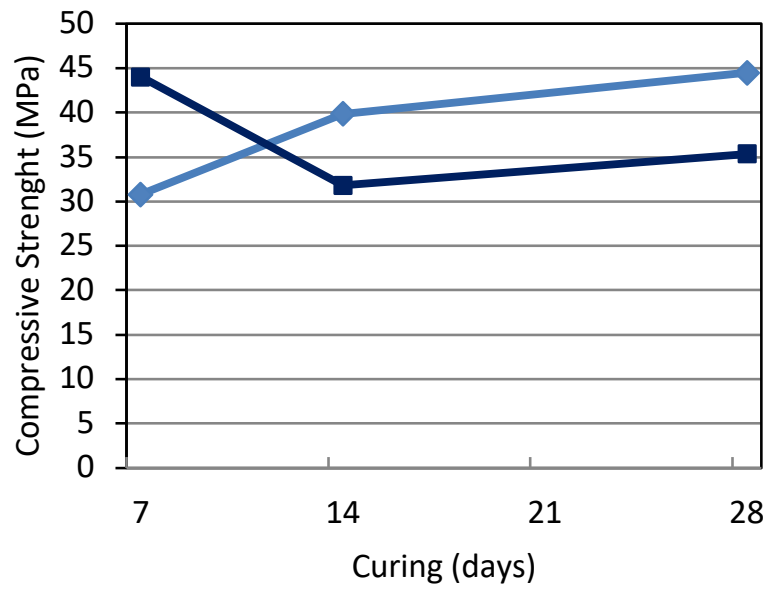

$\leadsto 60^{\circ} \mathrm{C}$ W80G20 $12 \mathrm{M}-80^{\circ} \mathrm{C}$ W80G20 12M
Fig 6. Compressive strength of alkali-activated mixtures with different curing temperatures.

Considering these variables the mixture W80G20 with $20 \%$ of $\mathrm{G}$ content, a molar concentration of $12 \mathrm{M}$, and a curing period of 7 days in a ventilated oven at $60^{\circ} \mathrm{C}$ was the one that presented a greater increase of compressive strength over time. Therefore this mixture was used forward as reference mixture (REF) to add different percentages of aggregates.

\subsection{Aggregates influence on compressive strength}

Several alkali-activated samples were prepared adding to REF $25 \%$ to $50 \%$ of precursor's mass of the following aggregates: 4 to $8 \mathrm{~mm}$ expanded cork granules $(\mathrm{C}), 1$ to $2 \mathrm{~mm}$ river sand (S), 1 to $2 \mathrm{~mm}$ expanded clay (A). These mixtures were tested to compressive strength with 7 days of curing at $60^{\circ} \mathrm{C}$ (Fig.7).

Mixture S25 was the only one that revealed better compressive strength than REF. This may results from the fact that sand has silica in its composition helping to increase the amount of amorphous material to react in the mixture. However sand was the aggregate that revealed greater loss of resistance when the percentage is increased to $50 \%$. Mixtures with $25 \mathrm{C}$ and $50 \mathrm{C}$ were the ones with lower compressive strength, 17 and $13 \mathrm{MPa}$, respectively. These results represent a $45-58 \%$ loss of strength compared to REF. However the results are satisfactory for all mixtures given that it is desired to develop a cladding material.

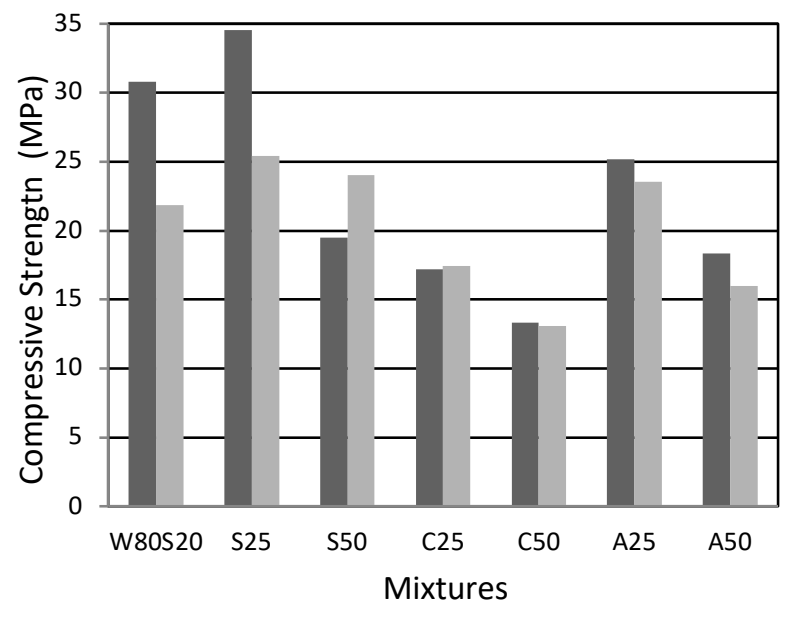

$\square 7$ days cure $60^{\circ} \mathrm{C} \square 7$ days cure $60^{\circ} \mathrm{C}+24 \mathrm{~h}$ water immersion

Fig 7. Compressive strength of mixtures with aggregates.

\subsection{Effect of water immersion on mixtures compressive strength}

Six specimens of the same mixtures prepared to test the influence of aggregates on compressive strength were used for this test. A comparative analysis is shown in Fig. 7. The results indicate that all mixtures tend to loose compressive strength after water immersion for $24 \mathrm{~h}$. Only S50 presents a $12 \%$ increase of compressive strength 
compared to REF (W80G20). This increase may result from the presence of amorphous silica in the sand which also reacts.

It must be pointed out that cork mixtures were the only ones in which the process of water immersion for $24 \mathrm{~h}$ didn't affect their compressive strength.

\subsection{Influence of aggregates in water absorption by capillarity}

Water absorption of these specimens was compared with the reference mixture REF with no aggregates (Fig. 8). Mixture $\mathrm{C} 25$ is the one that shows higher water absorption along the time. However S25 shows higher results in the first hours. Regarding the increase of aggregates percentage from $25 \%$ to $50 \%$ it proves to be detrimental, leading to a significant reduction in capillary absorption capacity in all mixtures. Although expanded clay is a porous material, the blends with this material have been found to have the lowest capillary absorption capacity of all mixtures with aggregates.

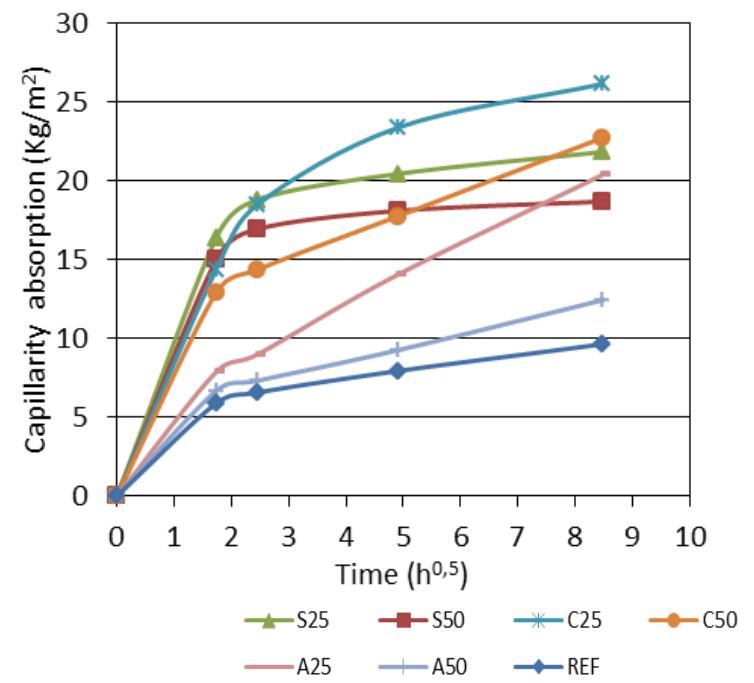

Fig 8. Water absorption by capillarity of alkali-activated mixtures with aggregates.

\subsection{Relation between mixtures density and water absorption}

By establishing the relation between mixtures bulk density and water absorption coefficient (Fig. 9), we can identify which are the most advantageous for the design of GEOGREEN modules.

All aggregates contribute to increase the mixture water absorption coefficient (Aw). However, the ones with better results are C25 with $4,77 \mathrm{~kg} / \mathrm{m}^{2} . \mathrm{h}^{\mathrm{s}}$ and $\mathrm{S} 25$ with $4,11 \mathrm{~kg} / \mathrm{m}^{2} h^{\text {os. }}$.

The results indicate that all mixtures containing sand, S25 and S50, have higher bulk density than REF. The mixture with expanded clay, A25 and A50, are the ones with lower water absorption.
C50 is the mixture with lowest bulk density, 1,55 $\mathrm{g} / \mathrm{cm}^{3}$ and $\mathrm{C} 25$ is the mixture with highest water absorption coefficient.

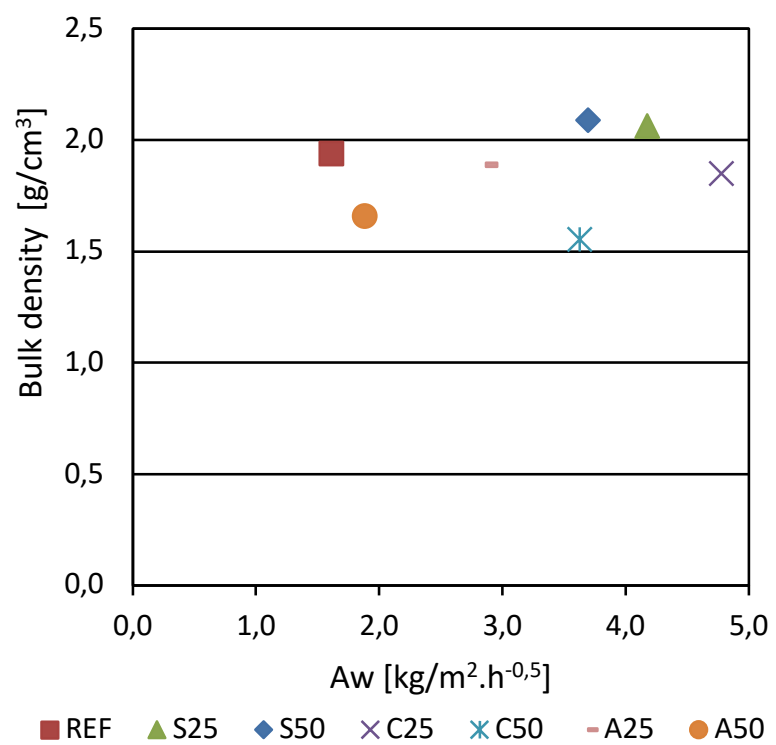

Fig 9. Water absorption coefficient of alkali-activated mixtures with aggregates.

\section{Conclusions}

Mixture S25 can reach a maximum compressive strength of almost $35 \mathrm{MPa}$, after 7 curing days at a constant temperature of $60^{\circ} \mathrm{C}$ in a ventilated oven. However a $30 \%$ compressive strength loss of is observed after immersion in water for $24 \mathrm{~h}$.

Capillarity absorption coefficient can reach between $1,89 \mathrm{~kg} / \mathrm{m}^{2}$. hos for A50 to 4,77 kg/m². hos for C25. Density can be reduced with the introduction of expanded cork granules as aggregates in the mixture. C50 enables a final density of $1,55 \mathrm{~g} / \mathrm{cm} 3$, which represents a $20 \%$ reduction from REF.

Therefore expanded cork granules are considered the most suitable aggregate to add to these alkali-activated mixtures.

Results indicate that alkali-activated mixture $\mathrm{C} 25$ that has the most appropriate combination of properties to be used in GEOGREEN modules. It obtained one of the lowest compressive strength with $17 \mathrm{MPa}$. However, in obtained a water absorption coefficient of $4,77 \mathrm{~kg} / \mathrm{m}^{2} . h^{0.5}$ and a density of $1,85 \mathrm{~g} / \mathrm{cm}^{3}$.

Further tests could be prepared to identify if the percentage of cork granules could be slightly increased.

These studies were carried within the scope of SFRH / BD / 98422/2013 PhD Grant funded by the Foundation for Science and Technology (FCT) and Human Potential Operational Program (POPH). The tests were completed in the construction technology and mechanic test laboratory of University of Beira Interior. All studies were developed at C-MADE, Centre of Materials and Building Technologies at the University of Beira Interior. This work appears in the sequence of the research FCT 
funded project PTDC/ECM/113922/2009 "Waste Geopolymeric binder-based natural vegetated panels for energy-efficient building green roofs and facades".

Partial finance support from the European Commission Horizon 2020 Marie Skłodowska- Curie Research and Innovation Staff Exchange scheme through Grant No. 645696 [i.e., the Reuse of Mining Waste into Innovative Geopolymeric-based Structural Panels, Precast, Ready Mixes and Insitu Applications (REMINE) project] is also greatly acknowledged.

\section{References}

1. Eurostat, Generation of waste by waste category EU28 (2014)

2. A. Wheeler, Report NI 43-101 Technical Report on the mineral resources and reserves of the Panasqueira mine, Portugal (2016)

3. F. Pacheco-Torgal, J. Castro-Gomes and S. Jalali, Tungsten mine waste geopolymeric binder: Preliminary hydration products investigations, Construction and Building Materials, 23, 200-209 (2009)

4. J. Centeio, Propriedades físicas de argamassa geopolimérica de lamas residuais das minas da Panasqueira, Dissertação para obtenção do Grau de Mestre em Engenharia Civil: Estruturas e Construção, Universidade da Beira Interior, Covilhã, Portugal (2011)

5. J. M. R. Filipe, Ativação alcalina de lamas residuais das minas da Panasqueira incorporando vidro moído, Universidade da Beira Interior, Dissertação para obtenção do Grau de Mestre em Engenharia Civil, Covilhã (2013)

6. G. Kastiukas, X. Zhou and J. Castro-Gomes, Development and optimisation of phase change material - impregnated lightweight aggregates for geopolymer composites made from aluminosilicate rich mud and milled glass powder, Construction and Building Materials, 110 (2016)

7. D. Marcos and P. Alves, Non- Structural Lightweight Concrete Produced with Volcanic Scoria from São Miguel Island, Instituto Superior Técnico, Lisbon (2014)

8. P. Barroca, Comportamento reológico e mecânico de argamassas com agregados leves, Universidade da Beira Interior (2013)

9. M. Manso and J. Castro-Gomes, Green wall systems: a review of their characteristics, Renewable and sustainable energy reviews, 41, 863-871 (2015)

10. M. Manso, A. Virtudes, J. Castro-Gomes, Development of a modular system for vegetated surfaces in new buildings and retrofitting, World Green Roof Congress, Copenhagen (2012)

11. E. Commission, Towards an EU Research and Innovation policy agenda for Nature-Based Solutions and Re-Naturing Cities (2015)
12. A. Virtudes and M. Manso, Applications of Green Walls in Urban Design, IOP Conf. Series: Earth and Environmental Science, World Multidisciplinary Earth Sciences Symposium (WMESS 2016), 44 (2016)

13. A. Virtudes and M. Manso, Green façades: as a feature in urban design, Proceedings of ICEUBI, International Conference on Engineering (2011)

14. E. Alexandri and P. Jones, Temperature decreases in an urban canyon due to green walls and green roofs in diverse climates, Building and Environment, 43, 480-493 (2008)

15. A. Rahman, F. Yeok and A. Amir, The building thermal performance and carbon sequestration evaluation for Psophocarpus tetrogonobulus on biofaçade wall in the tropical environment, World Academy of Science, Engineering and Technology. International Journal of Environmental, Chemical, Ecological, Geological and Geophysical Engineering, 5 (4) (2011)

16. M. Bruse, M. Thönnessen and U. Radke, Practical and theoretical investigation of the influence of facade greening on the distribution of heavy metals in urban streets (1999) Available: http://www.envimet.com/documents/papers/facade1999.pdf (accessed 17.01.2012).

17. A. Virtudes and M. Manso, "Green Walls Benefits in Contemporary City," in 1-ICAUD, Proceedings of First International Conference on Architecture and Urban Design (2012)

18. S. K. Weiler and K. Scholz-Barth, Green Roof Systems - A Guide to the planning, design, and construction of landscapes over structure, New Jersey: John Wiley and Sons, Inc. (2009)

19. R. Francis and J. Lorimer, Urban reconciliation ecology: The potential of living roofs and walls, Journal of Environmental Management, 92, 14291437 (2011)

20. J. Lundholm, Green Roofs and Facades: A Habitat Template Approach, Urban Habitats, 4, 87-101, (2006)

21. B. Bass, Green roofs and green walls: Potential energy savings in winter, Report on Phase 1, Adaptation \& Impacts Research Division Environment Canada at University of Toronto Centre for Environment (2007)

22. J. Yoshimi and H. Altan, Thermal simulations on the effects of vegetated walls on indoor building environments, in Proceedings of Building Simulation 2011: 12th Conference of International Building Performance Simulation Association, Sydney (2011)

23. G. Pérez, J. Coma, I. Martorell and L. F. Cabeza, "Vertical Greenery Systems (VGS) for energy saving in buildings: A review, Renewable and Sustainable Energy Reviews, 39, 139-165, November (2014) 
24. M. Manso and J. Castro-Gomes, Thermal analysis of a new modular system for green walls, Journal of Building Engineering, 7, 53- 62 (2016)

25. M. R. Ismail, Quiet environment: Acoustics of vertical green wall systems of the Islamic urban form, Frontiers of Architectural Research, 2, 162177 (2013)

26. N. H. Wong, A. Y. K. Tan, P. Y. Tan, K. Chiang and N. C. Wong, Acoustics evaluation of vertical greenery systems for building walls, Building and Environment, 45, 411-420 (2010)

27. M. Manso, J. P. Castro-Gomes, M. Marchacz, M. Górski, L. Dulak and R. Zuchowski, Acoustic evaluation of a new modular system form green roofs and green walls, ACEE Architecture, Civil Engineering and Environment, The Silesian University of Technology, 2, 99-108 (2017)

28. M. Manso, J. P. Castro-Gomes, A.L. Virtudes, A. Albuquerque, J. Lanzinha, P. Silva, J.Carlos, F. Sousa, PT106022, Conjunto acoplável de peças modulares para execução de superfícies ajardinadas, INPI (2012)

29. M. Manso, J. P. Castro-Gomes, P. Dinho, A.L. Virtudes, F. Delgado, Modular system design for vegetated surfaces. A proposal for energy-efficient buildings, BESS-SB13 CALIFORNIA: Advancing Towards Net Zero, Pomona, California, USA (2013)

30. BSI, BS EN 196-1 Methods of testing cement. Determination of strength, BSI Standards Publication (2016)

31. LNEC, Especificação do LNEC E393-1993 Betões: Determinação de Absorção de Água por Capilaridade, LNEC (1993) 